EISSN: 2706 -7947 ISSN: 2077- 4613

DOI: 10.36632/mejas/2021.11.3.58

Journal homepage: www.curresweb.com

Pages: 785-791

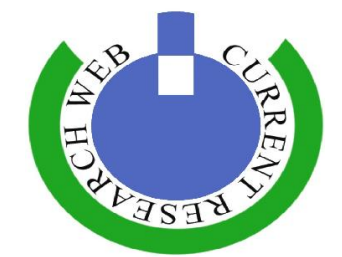

\title{
Assessment of Different Ventilation Methods for Compost Production
}

\author{
Fatma S. Moursy', M.A.M. El-Esaily ${ }^{2}$, Ihab I. Sadek ${ }^{1}$, Adel M.R.A. Abdelaziz ${ }^{3}$ and \\ Medhat M. Boulos ${ }^{4}$
}

${ }^{I}$ Climate Modification Research Department, Central Laboratory for Agricultural Climate (CLAC), Agricultural Research Center (ARC), Giza, Egypt.

${ }^{2}$ Department of Bioengineering System, Agricultural Engineering Research Institute (A.En.R.I.), Agricultural Research Center (ARC), Giza, Egypt.

${ }^{3}$ Central Laboratory of Organic Agriculture (CLOA), Agricultural Research Center (ARC), Giza, Egypt.

${ }^{4}$ Deparment of Irrigation Research, Agricultural Engineering Research Institute (A.En.R.I.), Agricultural Research Center (ARC), Giza, Egypt.

\author{
Received: 10 August $2021 \quad$ Accepted: 15 Sept. $2021 \quad$ Published: 25 Sept. 2021
}

\begin{abstract}
Composting methods have resilient influence on spot differences in the physical and chemical characteristics of compost maturity. In the current study which carried out at Central Laboratory for Agricultural Climate (CLAC), from $1^{\text {st }}$ October 2019 to $15^{\text {th }}$ March 2020. Three ventilation methods for composting were evaluated, local turners, manual turning using hand shovels, and natural ventilation, the processes were examined between a week intervals up to 22 weeks. The gradual changes in physicochemical characteristics (temperature, $\mathrm{pH}$, moisture content and $\mathrm{C} \backslash \mathrm{N}$ ratio) related by compost stability and maturity were studied and compared; the results showed that, mechanical ventilation and manual turning were higher than in the natural ventilation. The optimum level for compost stability and maturity parameters like moisture content, $\mathrm{C} \backslash \mathrm{N}$ ratio, $\mathrm{pH}$, particle size, odor, and composting time were reached earlier in mechanical ventilation process as compared to manual turning ventilation processes. The final investigation results indicated that, using mechanical turning give best compost characteristics compared with natural or manual ventilation.
\end{abstract}

Keywords: Composting, Compost quality, Aeration methods, Waste recycle.

\section{Introduction}

Composting is an aerobic fermentation process caused by micro-organism mediated, where, the solid organic materials were digested and converted into other stable compounds, the new product is known compost, and this compost has many advantages for the soil, where it is improve the physicchemical and microbiological properties (Sanchez et al., 2017).

Compost producing process is an ecological complex process, where the temperature, oxygen, $\mathrm{pH}$, moisture content, organic matter and many other factors are in a state of overlapping and a continuous mutability until to reach to the compost maturity. Compost producing process is carried out by using many different systems, which include turned windrows, static piles with forced ventilation and in-vessel systems. (Alexander, 2007). Composting process could be defined also as a biological process under control conditions used to digest the organic wastes and transform these wastes into organic fertilizer, the ventilation method is the influencing factor in the compost production process, and it helps to ensure the growth of aerobic microbes.

To clarify the effect of ventilation methods on the compost maturity and quality (Zhi-Qiang Xiong et al., 2017) studied the effect of ventilation rates on nitrogen losses during compost producing process, and they found that ventilation rate highly affected on $\mathrm{O}_{2}$ content with all conditions, as well

Corresponding Author: Fatma S. Moursy, Climate Modification Research Department, Central Laboratory for Agricultural Climate (CLAC), Agricultural Research Center (ARC), Giza, Egypt.

E-mail: drfatmamoursy@yahoo.com 
as moisture content, nitrate and nitrogen loss. They are found also that $\mathrm{NH}_{3}$ emissions were increased with the increasing of ventilation rates and increased at high temperatures owing to nitrogen loss. The main results from this research are the ventilation rate had a significant effect on total nitrogen loses and ammonia emissions. Many physical factors have significant effect on the stability and maturity of the compost, like ventilation methods, temperature, moisture content and $\mathrm{pH}$ (Guo et al., 2012).

Ventilation process has the mainly effect on compost component and maturity; where the ventilation process provides the oxygen needed for aerobic biochemical interactions, ventilation process helps to removes heat generated from the interaction, excess moisture and carbon dioxide and other products of disintegration (Shimizu, 2017).

On other hand, the effect of ventilation rate on compost quality, nitrogen losses, and energy required were studied by (Scaglia et al., 2011). The results found that the anaerobic conditions could be caused by the deficient ventilation, that is due to the shortage of oxygen, on the other hand too much ventilation increase the production costs and decrease the speed of composting process by losing the heat, water, and ammonia, causing nitrogen loss. The up keeping of suitable oxygen content during composting process, lead to limit the formation of anaerobic zones and thereby avoid the generation of intermediate products of anaerobic metabolism, compost producing process helps to decrease the waste management problems including odors of manure, pathogens, groundwater pollution, and utilization costs (Tirado, 2008).

Waste management in rural areas has focused more on usefully reusing it as feed for agricultural purposes, with the aim of increasing environmental awareness and reducing costs associated with disposing liquid wastes, organic waste and bio-solids (Sumner, 2000). Animal manures, agricultural wastes, food processing wastes and other agricultural byproducts have could be considered a good organic fertilizer for the soil cause of highly constants of nutrients and organic matter. Compost producing process is a one method of wastes recycling for reuse as a soil organic fertilizer (Defoer and Van Langenhove, 2002; Danso et al., 2006).

Composting process starts when the organic wastes are motley to realize a $\mathrm{ClN}$ ratio, moisture content and suitable space that ensure a good condition for digestion and degradation to produce the compost (Illmer et al., 2007). Temperature increasing leads to increase the compost decomposition reactions. Although this rise is significant, it negatively affects the microbial assemblages during the process of decomposition, where the suitable temperature degree is directly affected by the microbial activity. Therefore, the ventilation rates must be good to maintain an adequate level of temperature (Nelson et al., 2006). Temperature is the main indicator, where the composting processes has been taken the place between two ranges known as mesophilic $\left(10-40^{\circ} \mathrm{C}\right)$ and thermophilic (above $40^{\circ} \mathrm{C}$ ), and the most composting processes takes place at temperatures between $45^{\circ} \mathrm{C}$ and $65^{\circ} \mathrm{C}$. The temperatures of thermophilic result in more fast disintegration and pathogen weed seed and fly larvae devastation (Alexander, 2007; Tateda et al., 2005). Moreover, CWN ratio has highly effect on composting processes and on the losses of nitrogen throughout composting process too (Illmer et al., 2007).

Therefore, piles size and piles rotating rate directly affect composting costs due to the machinery systems used and the required area to each pile. However the size of a pile is limited by the machinery systems, the depth of permeation of oxygen and by high temperatures that develop in the center of the pile that can inhibit microbial activity (Guo et al., 2007; Halet et al., 2006).

This study aims to produce a high quality compost form agricultural wastes, suggest the best ventilation method for producing processes, that by studying effect of three different ventilation methods on the compost maturity and quality

\section{Materials and Methods}

This exprimental were carried out at Central Laboratory for Agricultural Climate (CLAC), from $1^{\text {st }}$ October 2019 to $15^{\text {th }}$ March 2020.

\subsection{Raw materials}

Four types of raw materials were selected (corn stalks $30 \%$, rice straw $25 \%$, vegetables wastes $30 \%$, and mixed manure $15 \%$ ). These raw materials were chopped and divided into three piles. The dimensions of each pile were $1.3 * 0.7 * 10 \mathrm{~m}(\mathrm{~W}, \mathrm{H}, \mathrm{L}) .100 \mathrm{~g}$ of samples were collected from three 
different depths $(10 \mathrm{~cm}, 30 \mathrm{~cm}$ and $50 \mathrm{~cm}$ ), and three different points of the piles length every $2 \mathrm{~m}$, on week zero, 4, 8, 12, and 16 after ventilation before turning according to (Zue et al., 2004).

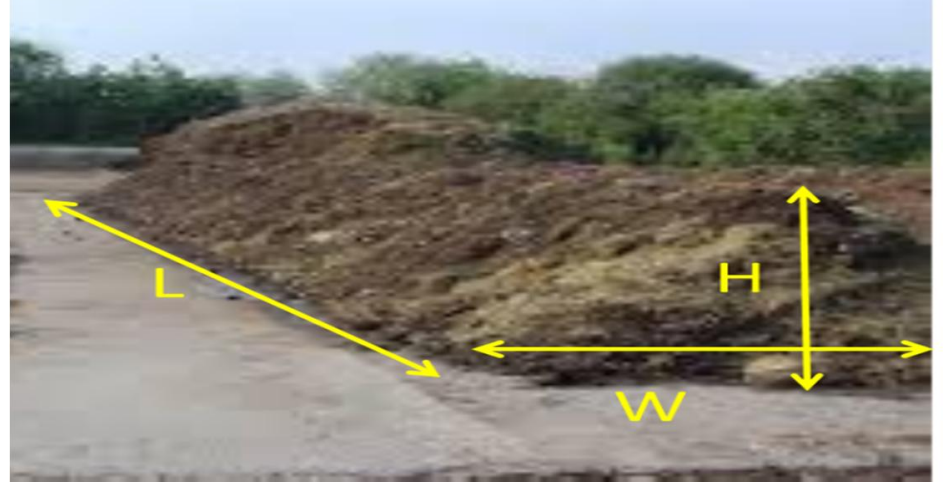

\subsection{Ventilation methods}

To providing air and enough oxygen for aerobic biodegradation to remove excess water vapor, heat, and gases, three ventilation methods were selected to study and evaluate the performance characteristic for each ventilation methods.
A) Natural ventilation "Pile 1",
B) Ventilation using manual turning "Pile 2", and
C) Mechanical ventilation "Pile 3"
D)

Each pile 2 and 3 were turned twice a week for 10 weeks then once a week for five weeks. Also, turning was started when the pile temperature ranged from 60 to $70^{\circ} \mathrm{C}$.

\subsection{Temperature}

The pile temperature profiles were measured manually at three different depths $(5 \mathrm{~cm}, 30 \mathrm{~cm}$ and $50 \mathrm{~cm}$ ), using a series of portable K-thermocouples (Omega).

\subsection{Moisture content}

Sample weighted $250 \mathrm{~g}$ was dried at $105 \pm 5^{\circ} \mathrm{C}$ for $24 \mathrm{~h}$ until a constant weight. The moisture content (\%) was calculated as the mass loss due to water removal $(\mathrm{g} / \mathrm{g})$ divided by the wet (Michel et al., 1993).

\subsection{Particle size}

The compost samples were dried and the particle size was determined. The method was implemented as described according to ASAE Standards S424.1, A set of seven square-hole sieves were used consisting of numbers $3.5,6,10,14,20,35$ and 60 , with screen openings of 5.66, 3.36, 2, 1.41, $0.85,0.5$ and $0.246 \mathrm{~mm}$, respectively.

\section{6. $\mathrm{C} \backslash \mathbf{N}$ ratio}

The organic carbon was determined according to FAO Soil Bulletin (1989). Total nitrogen was determined using kjeldahl digestion and distillation method as described by FAO Soil Bulletin (1989).

\section{7. $\mathrm{pH}$}

Compost $\mathrm{pH}$ was determined by taken 10 grams of compost and added to $100 \mathrm{ml}$ of deionized water then $\mathrm{pH}$ determined using a $\mathrm{pH}$ electrode (Carnes and Lossin, 1970).

\section{Results and Discussion}

\subsection{The properties of the initial raw materials:}

At the start and after preparing and mixing the three piles 10 samples were taken from each pile and analyzed (Table 1). 
Table 1: Properties of the initial raw materials:

\begin{tabular}{ccccc}
\hline Piles No. & Temp. $^{\circ} \mathbf{C}$ & MC \% & C/N ratio & pH \\
\hline Pile 1 & $27+0.8$ & $29.3 \%+1.1$ & $40 / 1+1.6$ & $5.9+0.5$ \\
Pile 2 & $27.5+0.9$ & $29.3 \%+1.1$ & $40 / 1+1.6$ & $5.7+0.5$ \\
Pile 3 & $27.7+1.0$ & $29.3 \%+1.1$ & $40 / 1+1.6$ & $6+0.5$ \\
\hline
\end{tabular}

\subsection{Average temperature profiles:}

The results comparisons for analyzed compost after every week were conducted out for a period of 22 weeks. The variations in the parameters during different times of the study were documented graphically and tabulated for three ventilation method. The rising of the average temperature degree is the integral part of the composting process. In addition, the increasing in average temperature degree is an essential component towards sterilization of the compost (Haug, 1993). The increasing of the average temperature degree after 7 days is caused by the microbial activity, and it was detected in all types of three ventilation method (Fig. 1), followed by decline due to less availability of organic carbon, these results are also described by (Hagerty et al., 1973). The difference in average temperature degree was recorded in all types of ventilation. In the natural ventilation the maximum average temperature increased was $60^{\circ} \mathrm{C}$ on $5^{\text {th }}$ week and $70^{\circ} \mathrm{C}$ on sixth week. Whereas, in ventilation using manual turning obtained the average temperature was $55^{\circ} \mathrm{C}$ on $5^{\text {th }}$ week and $62^{\circ} \mathrm{C}$ on sixth week (Fig. 1). The average temperature of mechanical turning was lowest as compared to other ventilation due to its good ventilation average temperature recorded was $53^{\circ} \mathrm{C}$ on $5^{\text {th }}$ week and $58^{\circ} \mathrm{C}$ on sixth week. Moreover, temperature can be used as an indicator of the composting performance and it is very important for killing of pathogens and weed seeds in the compost.

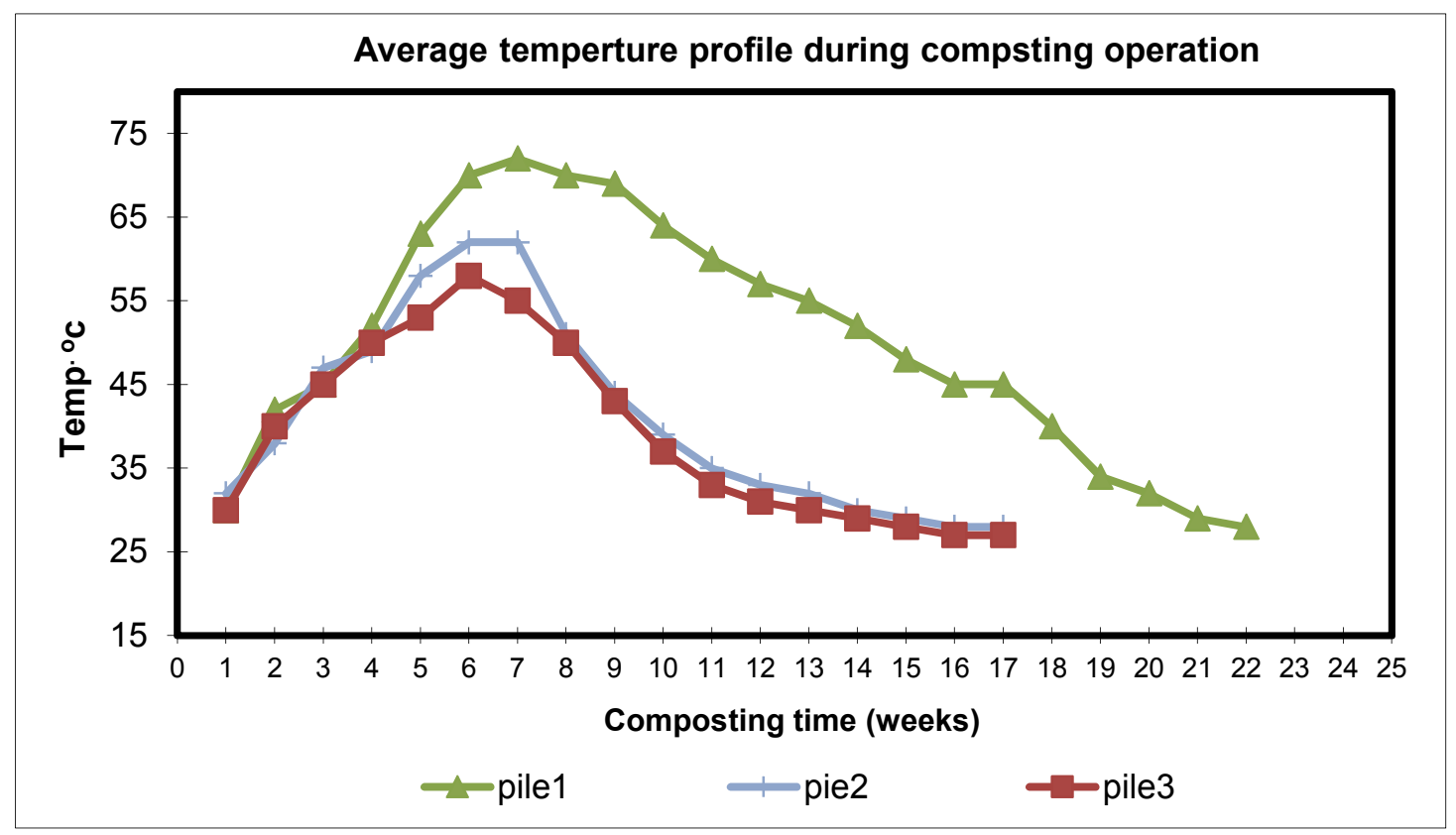

Fig. 1: Average temperature profile during composting operation.

Furthermore, the average temperature data showed that, the average temperature decreased for piles 2 and 3 reached near the atmospheric temperature after 13 weeks, while, it decreased near atmospheric temperature after 22 weeks for the pile 1.

\section{3. $\mathrm{pH}$ profiles}

Presented data in Figure 2, indicated that the $\mathrm{pH}$ started increasing for each pile from first week until 11 weeks for piles 2 and 3 and 14 weeks for pile 1 from composting process. After that, pH profile was started to decrease until reached to stability. This changing in $\mathrm{pH}$ is due to the metabolically activities resulted in the production of organic acids and release of ammonia. All organic wastes proper for composting processes have a range of $\mathrm{pH}$ from 6 to 7 but no specific $\mathrm{pH}$ is required for composting process the $\mathrm{pH}$ of the raw material (6.7) rise in all types of ventilation (Fig. 2), due to the organic acids 
produced by the fermentation of carbohydrates and lipids due to microorganisms (Gaur, 1997). The $\mathrm{pH}$ comeback to neutral level after the organic acids converted to $\mathrm{CO}_{2}$ by microbial activity, which is in agreement with the observation made by (Heo et al., 2004). At maturity aerobic process $\mathrm{pH}$ was gradually decreased and tended to be stable 7.5 to 7.8 , however $\mathrm{pH}$ cannot be considered as a good parameter to assess compost maturity agree with (Hernando et al., 1989).

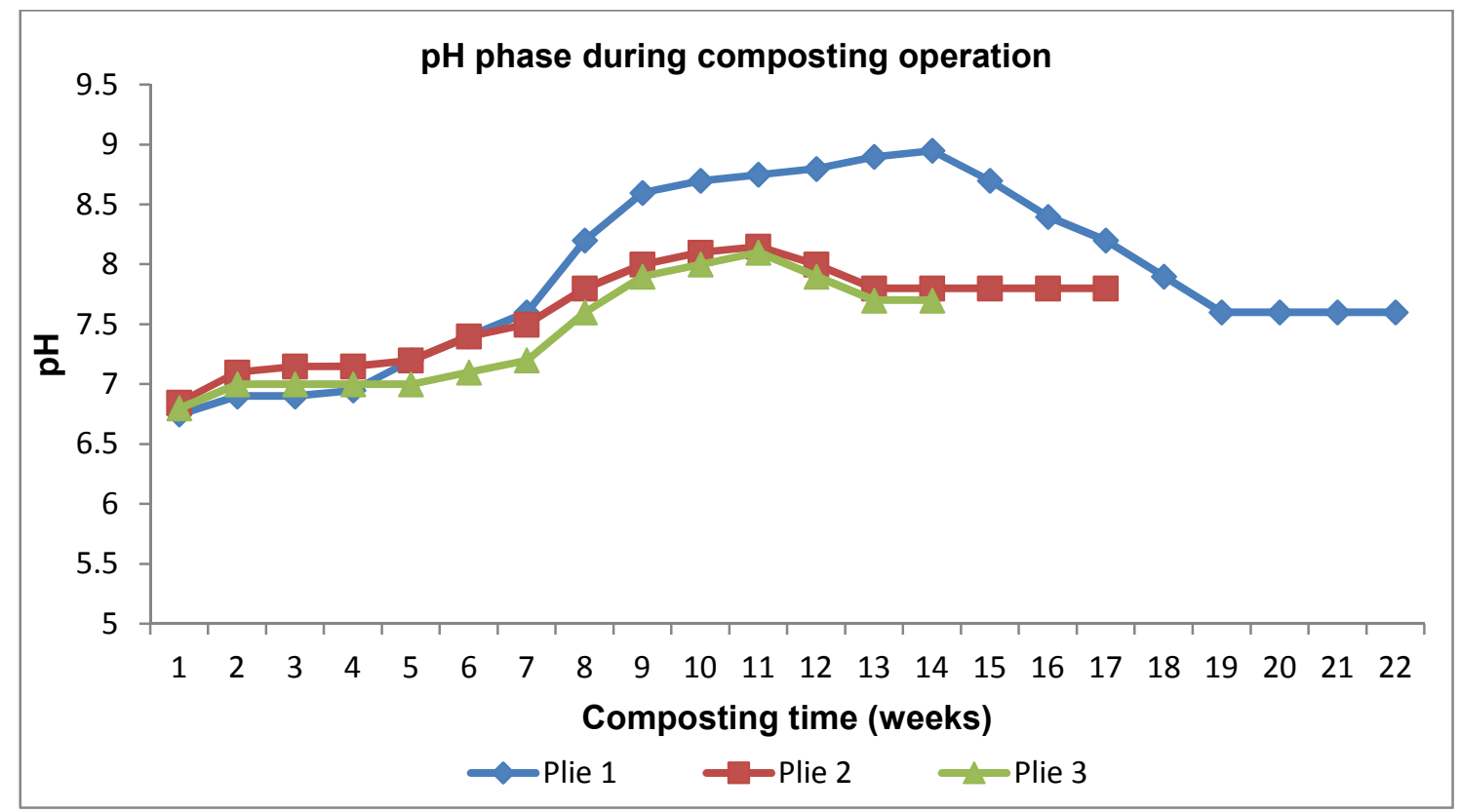

\section{4. $\mathbf{C} \backslash \mathbf{N}$ profiles}

Fig. 2: $\mathrm{pH}$ profile during composting operation.

Illustrated data in Figure 3 obtained that, $\mathrm{C} \backslash \mathrm{N}$ profiles were started reducing after first week to 17 weeks for pile 2 and 3 and 22 weeks for pile 1 from composting process for each pile. Also, the reduction percentage in $\mathrm{C} \backslash \mathrm{N}$ ratio value was $30.5 \%, 26.7 \%$ and $24 \%$ for neutral ventilation, manual ventilation and mechanical ventilation, respectively, (Fig. 3). This observation due to the carbon reduction was greater compared to $\mathrm{N}$ in all types of composting processes because microorganisms use carbon as an energy source and $\mathrm{N}$ to build the cell structure in the decomposition process. Higher reduction of carbon and nitrogen ratio in mechanical ventilation method was due to ventilation stable earlier than in manual ventilation the final $\mathrm{C} \backslash \mathrm{N}$ ratio was higher than recommended values. Natural ventilation is not suitable for land application. The $\mathrm{C} \backslash \mathrm{N}$ ratio for organic wastes is critical and usually used for the maturity degree of the compost (Bernal et al., 1998).

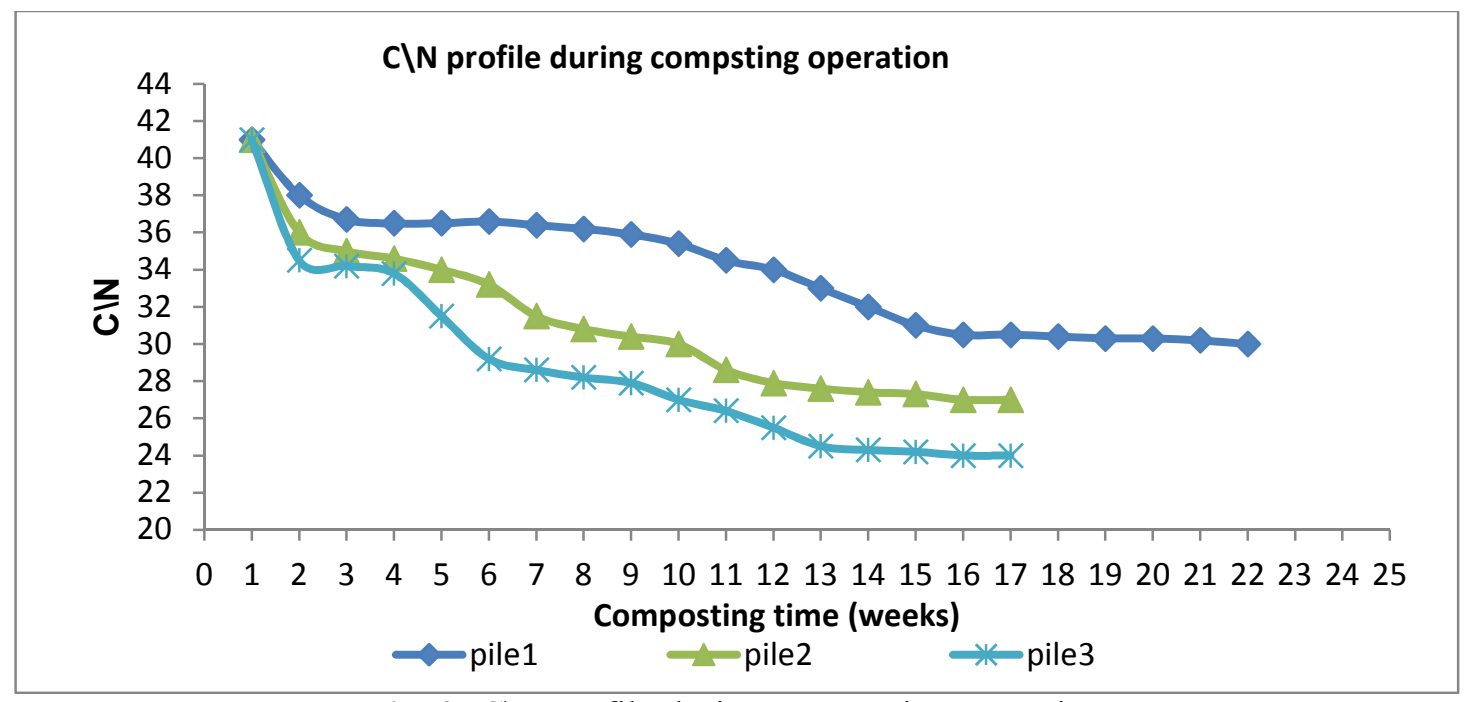

Fig. 3: $\mathrm{ClN}$ profile during composting operation. 


\subsection{Maturity stage}

The change in temperature, $\mathrm{pH}, \mathrm{C} / \mathrm{N}, \mathrm{MC}$, texture, color Odor and Particle size are the indicators of the end of composting operation. Final samples were analyzed to indicate and evaluate the properties of the final compost materials for the three piles shown in Table (2). Result show that compost produced after 22, 18 and 17 weeks for piles 1,2 and 3, respectively. The final analysis of the samples indicated that, there are significant differences in between the three systems with different agitation rates especially in odor and $\mathrm{ClN}$ ratio beside the period of composting and particle size. In addition, producing the compost by using mechanical ventilation method led to enhance the compost quality and faster the composting process more than other tested methods.

Table 2: The properties of the final compost materials.

\begin{tabular}{ccccccccc}
\hline Pile No. & Temp ${ }^{\mathbf{}} \mathbf{C}$ & MC \% & $\begin{array}{c}\text { ClN } \\
\text { ratio }\end{array}$ & pH & Texture & $\begin{array}{c}\text { Color } \\
\text { Intensity }\end{array}$ & Odor & $\begin{array}{c}\text { Particle } \\
\text { size } \\
(\mathbf{m m})\end{array}$ \\
\hline Pile 1 & $28+0.8$ & $45 \%+1.1$ & $30 / 1+1.6$ & $7.5+0.5$ & Cruse & Light black & Acceptable & 18 \\
Pile2 & $28+0.8$ & $42 \%+1.1$ & $27 / 1+1.6$ & $7.8+0.5$ & Soft & Dark brown & Good & 15 \\
Pile 3 & $28+0.8$ & $40 \%+1.1$ & $22 / 1+1.6$ & $7.5+0.5$ & Soft & Brown & Good & 8 \\
\hline
\end{tabular}

\section{Conclusion}

The results showed that, the mechanical ventilation method is the most suitable methods for compost production comparing with the other two methods in this study, where, it gave the highest nitrogen level and reached to maturity degree earlier after 13 weeks, and gave the optimum properties of compost especially in $\mathrm{CWN}$ (22:1), $\mathrm{pH}$ (7.5) and average particle size (8mm).

\section{References}

Alexander, P.D., 2007. Effect of turning and vessel type on compost temperature and composition in backyard (Amateur) composting. Comp Sci. Util., 15(3): 167-175.

Bernal, M.P., C. Paredes, M.A. Sanchez-Monedero, and J. Cegarra, 1998. Maturity and stability parameters of composts prepared with a wide range of organic wastes. Bioresource Technology, 63: 91-99.

Brodie, H.L., E.C. Lewis, and P. Condon 2000. A comparison of static pile and turned windrow methods for poultry litter compost production. Compost Science and Utilization, 8(3):178-189

Carnes, R.A. and R.D. Lossin 1970. An investigation of the $\mathrm{pH}$ characteristics of Compost. Comp Sci. Util., 11: 18-21.

Danso, G., P. Drechsel, S. Fialor and M. Giordano, 2006. Estimating the demand for municipal waste compost via farmers' willingness-to-pay in Ghana. Waste Management, 26(12): 1400-1409.

Defoer, N. and H. Van Langenhove 2002. Odour emissions during yard waste composting: Effect of turning frequency. Microbiology of Composting, 561-569.

FAO Soil Bulletin. 1989. Soil and plant testing, 38/2 250.

Gaur, C., 1997. Bulky organic manures and crop residues. In: Tandon H. L. S, Ed, Organic Manures, Recyclable Waste and bio fertilizers, FDCO, New Delhi, India, 37.

Guo, R., G. Li, T. Jiang, F. Schuchardt, T. Chen, Y. Zhao, and Y. Shen, 2012. Effect of ventilation rate, $\mathrm{C} / \mathrm{N}$ ratio and moisture content on the stability and maturity of compost. Bioresour Technol., 112:171-178.

Guo, Y., N. Zhu, S. Zhu, and C. Deng, 2007. Molecular phylogenetic diversity of bacteria and its spatial distribution in composts. Journal of Applied Microbiology, 103(4): 1344-1354.

Hagerty, J.D., J.L. Pavoni and J.E. Heer, 1973. Solid Waste Management. Van Nostrand Reinhold Company, New York US, App 312.

Halet, D., N. Boon and W. Verstraete, 2006. Community dynamics of methanotrophic bacteria during composting of organic matter. Journal of Bioscience and Bioengineering, 101(4): 297-302.

Haug, R.T. (1993). The practical handbook of compost engineering. Lewis Pub., 717.

Heo, N.H., S.C. Park and H. Kang 2004. Effects of mixture ratio and hydraulic retention time on singlestage anaerobic co-digestion of food waste and waste activated sludge. J. Environ. Sci. Health, A39 (7): 1739-1756. 
Hernando, S., M.C. Lobo and A. Polo, 1989. Effect of the application of municipal refuse compost on the physical and chemical properties of a soil. The Science of the Total Environment, 81(82): 589596.

Illmer, P., C. Malin, S. Farbmacher, A.O. Wagner and J. Mair, 2007. Chemical and biochemical parameters during composting of lawn clippings with special regard to the efficiency of a compost starter kit. Compost science \& utilization, 15: 40-46.

Michel F.C., C.A. Reddy and L.J. Forney 1993. Yard waste composting: studies using different mixes of leaves and grass in a laboratory scale system. Comp Sci. Util. (1): 85-96.

Nelson, V.L., T.G. Crowe, M.A. Shah, and L.G. Watson 2006. Temperature and turning energy of composting feedlot manure at different moisture contents in southern Alberta. Canadian Biosystems Engineering, 48: 631-637.

Sánchez, Ó.J., D.A. Ospina and S. Montoya, 2017. Compost supplementation with nutrients and microorganisms in composting process. Waste Manag., 69: 136-153.

Scaglia, B., V. Orzi, A. Artola, X. Font, E. Davoli, A. Sanchez and F. Adani, 2011. Odours and volatile organic compounds emitted from municipal solid waste at different stage of decomposition and relationship with biological stability. Bioresource Technology, 102 (7): 4638-4645.

Shimizu, N., 2017. Process optimization of composting systems. In: Zhang D, Wei B (eds) Robotics and mechatronics for agriculture. CRC Press, Taylor \& Francis, 1-22.

Sumner, E.M., 2000. Beneficial Use of Effluents, wastes, and biosolids. Communications in Soil Science and Plant Analysis, 31(11-14): 1701-1715.

Tateda, M., L.D. Trung, I. Michihiko., and M. Fujita, 2005. "Optimal turning method of composting regarding hygienic safety." Journal of Environmental Sciences, 17(2): 194-199.

Tirado, S.M., 2008. Effects of turning frequency, pile size and season on physical, chemical and biological properties during composting of dairy manure/sawdust (DM+S). M.S Thesis. Ohio State University.

Zhi-Qiang, X., W. Guo-Xing, H. Zhao-Chen, Y. Lei, G. Ya-Mei, W. Yan-Jie, G. Ji-Dong, and W. WeiDong, 2017. Effect of ventilation rates on the composting processes and Nitrogen loss during composting. Applied Environmental Biotechnology, 2(1): 1-8.

Zue, N.D., D. Changyan and H. Qian, 2004. Performance characteristics of three systems in the swine manure composting. Agricultural and Biological Sciences, 95(3):319-26. 